\title{
Integrated Assessment of Economic Security in a Resource Region
}

\author{
E. B. Bukharova*, S. A. Samusenko**, and A. R. Semenova*** \\ Siberian federal binersity, Krashesparsh. Rassia \\ * mail: bach 5.3 immail.ril \\ **e-mail: sv samos

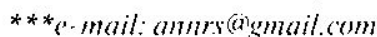 \\ Received ()ecober 17, 2016; in finsal form, April 19, 2017
}

\begin{abstract}
The article provides a comparative analysis of existing approaches to assessing regional cconomic security and proposes an original procedurt for integrated assessment ol economic security in resource regions. It includes an assessment of economic security thresholds based on Russia's strategic development priorities in comparison to the level of developed countries, as well as trend and muitivariate statistical analyses that help to identily crucial imbalances that threaten econonic development in a region. The assessment is based on data from Krisnoyarsk krai. We have identified several economic security paradoxes, namely, an imbalanced development of human assets and the enviromment, the industriat sector and hi-tech business, as well als disequilibrium in tinancial security. when are loreing the region to transtorm from an advanced indus. trial territory with a diversified economy into al "national storehouse" that has predominantly mining monoenterprises and to end up in the trap of technological inferiority.
\end{abstract}

Keywords: economic security, Krasnoyarsk krai, economic policy, resource bassed economy DOI: $10.1134 / \mathrm{S} 2079970.517030017$

\section{INTRODUCTION}

In addition to state, social, information, environmental. transport, and energy security, economic security is a crucial part of national security. Foreign researchers associate il with market dynamics and pecuitar features ol human pereeption and behavior; it is defined as the extent to which the human socicly can be protected against hardships when facing crises and economic losses |15|. Conversely, the approach accepted in Russia is depersonalized, macroeconomical, and characterized by a certain confusion of meanings. According to S.V. Kazantsev, securily in Russian literature is treated as a state, phenomenon, ability, measures or a system of such, condition or a set of such | $5 \mid$.

One of the first researchers to address economic security was Academician I.I. Abalkin, according 10 whom economic security is an economic state that makes it possible to promote an independent economic policy meeting national interests, as well as to control national resources [1]. This concept was fur ther elaborated by V.K. Senchagov, who added the factor of sustainability: national interests must be prolected and a socially oriented policy implemented even in light of unfavorable domestic and external processes $17 \mid$. They are threats defined as the sum of the conditions and factors creating the possibility of damaging national interests. Threats to economic security lorm with growing imbalances or contradictions between the purposes and objectives of modern society and the available tools and practices of the market economy. These threats are qualitative on the global scale and include mbalances in the real and linancial sectors, international commerce, imbalances of savings and investments, and a limited amount of unevenly allocaled resources $|8|$.

The integrated concept of economic sccurity is found in works by researchers from the Institute of Economics and Industrial Fnginecring. Siberian Branch, Russian Academy of Sciences (IE:Il: SB RAS) 15. 101. They have discovered a consistent relationship among security, threats, and immunity of national or regional economy as an object in terms of the category of situation and its definable characteristics. For instance. S.V. Kazantsev has elaborated a typology of threats and threatening objects, defined categorical relationships of threats and dangers (threat-causing situations), and interpreted security proper as the absence of danger or, in the presence of such, as a situation that allows full or partial protection of objects $|5|$.

With the escalating crisis and foreign and domestic imbalances, the federal subjects are becoming a formative and sustaining source of stability for the country's economy. In this respect, it is crucial to assess regional economic security systems. On the onc hand, they cannol be assessed autononously, becaluse many current imbalances (dangers) and disproportions of 
development ate determined by the role a region has historically played in the national economy. On the other land, the assessment must be balaneed and rely on analysis of a strong conglonerate of internal and external ties.

Despite the diverse range of meanings attributed to the concept of region. it is mose frequenty associated with an admonistrative teritorial entity, which is con ditioned not only by the historically formed steady cahnic. economic social, and calturat ties of this olject, but also by the existence of systemic purposes and development lasks and he union of mantagement. linancial, budgetary, and other systems. In the reproduclive approach suggested by $\Lambda . S$. Novoselov $|6|$, a region is a parl of a country 's conomic domain, an open system that is involved in cooperation with other systems in the territorial and international differentiation of labor. It is chatacteried by the union of economic processes in the social reproduction cycle and distinguished by peculiar natural geographical, social, resource, cultural, and infrastructural factors. In our opinion, regional ceonomic sectrity shotild be treated as the balanced condition of a region's economic, natural, cultural, and environmental subsystems as part of the country is common econsmic space. In this condinion, there are either no disproportions and threats to sustainable national and regional development or they are leveled by the system's self-regulation. Consecjuently, the lask of integrated assessment of a region's economic security is to identify the main disproportions in and threats to its sustainable development and to discover relations among crucial areas of regional economic security that reflect the dependences of economic indices on practical activitics in various fields of the economy.

The level of regional economic sectarty is assessed by different procedures. such as expert assessment (with qualitative parameters), trend method (the dynamic pattern of key lactors is delemined), maltivalriate statistical analysis (the reciprocal intluence of factors is determined), and a system of indicators as measured against 1 hresholds. The indicative method is the most popular procedure: first, it makes it possible to form an integrated idea ol security in all fields of activity in a region: second, it makes it possible to identify growing imbalances (dangers) and occurrence of threats; third, makes it possible to clange an approach lo diagnostics in response 10 transformations in the internal and external environments, strategy and purposes, imbalances and threats; fourth, this method can be used together with expert assessment, the trend method, and multivariate statistical analysis to expand analytical capabilities.

\section{FORMULATION OI THII PROBLEM}

There are three dominant approaches to economic security assessment abroad: (1) construction of weighted indices of economic security based on the risks or basic parameters of sociocconomic development |14, 15|: (2) comparison of a subject's alssels ol resources with the standard levels of their sulficency 10) assure expanded reproduction and achieve other purposes $|13|$; (3) assessment of revenue and expenses by amount, sufficiency, and volatility |12|.

The first Russian systems of economic security indicalors were constructed by I..!. Abalkin !II, S.Yu. Glayev |31, A.N. Mlarionov |4|, and V.K. Senchagov |7|. These sudies have been supplemented by researchers from the Institute of Ecomomics. Urat Brancli, Russian Academy of Sciences 191 , who have elaborated procedures for analy/ing regional security components (quality of life. geoecology) and analyzed areas of economic security assurance in light of regionat policy formation. The researchers from the IF:IE: SB RAS have proposed grading regions by immunity to basic internal and external threats using weighted and normalized indices and coefficients (demographic security, differentiation of macroeconomic factors, etc.) 15, 10|. The researchers from the Siberian fiederal University have elaborated an approach to assessing regional economic security in light of a crisis | III.

According to Abalkin, there are three main aspects of using the indicators. (1) The dynamic aspect shows changes in indicator priorities and thresholds over time. (2) The integrated aspect makes it necessary lo consider reciprocal influence, inconsistency, and reciprocal supplementation of indicators. (3) The target aspect shows the way the system of indicators is correlated with the current purposes and objectives of security assurance (survival, development, or advanced development), which are determined by economic cycle phases $|1|$.

There are a lot of works that proposed grouping indicators by economic security segments (sec, e.g., $11,8 \ldots 11)$. Indicators have thresholds, which corre sponds to the theory of threshold object values and allows distributing economic perlormance lactors in two groups of crisis condition: escalation of threats (indicator thresholds approximated) and instability zone (indicator thresholds exceeded). The long-term action of these factors indicates potential areas of economic erosion.

Our approach to diagnosing regional economic security has the following features that make it different from the existing procedures: (1) it is an integrated procedure and combines the indicative method with the trend and multivariate statistical analyses; $(2)$ it is intended to assess economic security of resource regions, where imbalances in development are determined by the monoindustrial structure of their economies, its low innovativeness, and degradation of human potential; (3) it structures security indicators by relevant priorities in the economic development of the Russian Federation and assures their connection to regional economic policy. 


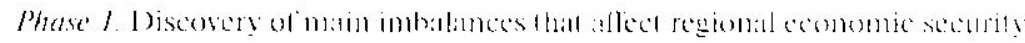

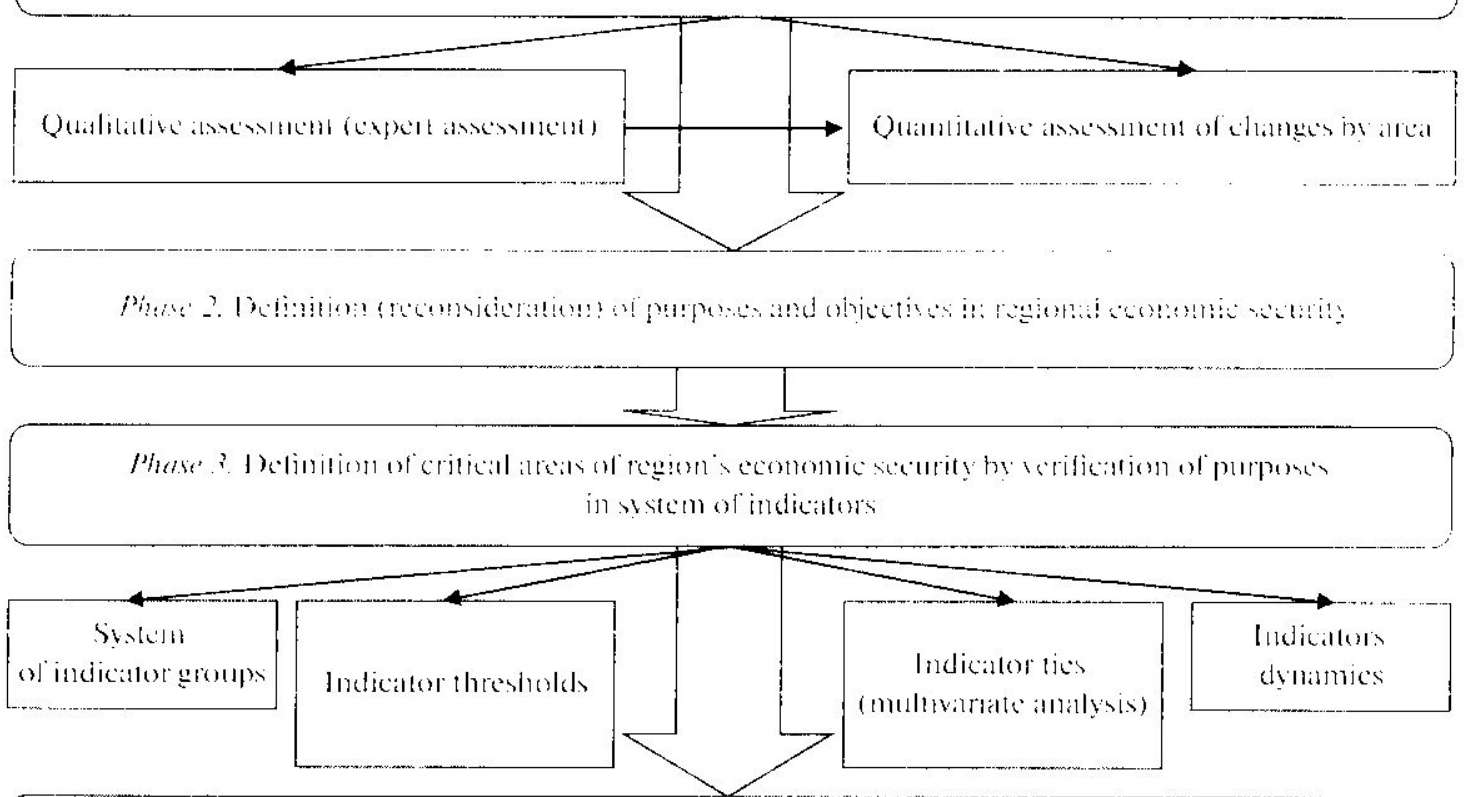

Phase 4. Integrated assessment ol economic security in al region by identilication of indicallor values

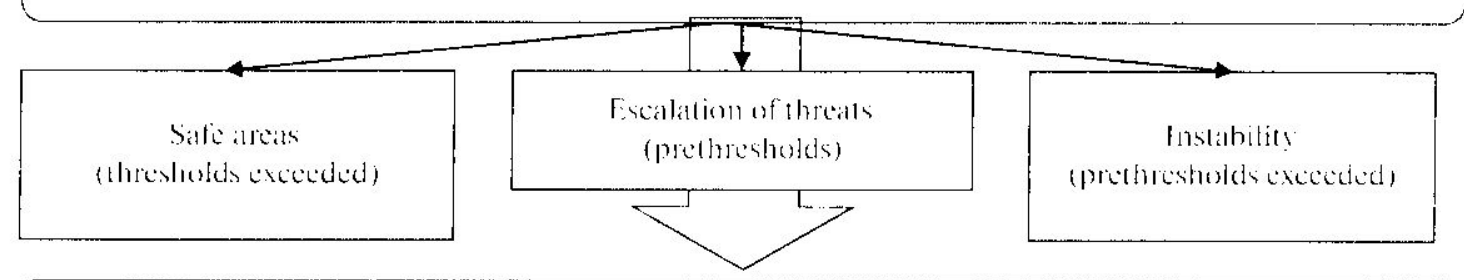

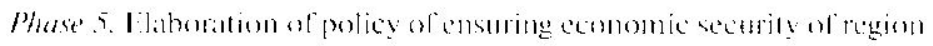

Fig. I. System of evaluatling regional ceonomic security ats basis of cconomic policy.

\section{METHOIDOIOGY OF THIE STLDY}

Fhe system ol indicative assessment of economic security of a resource region was constructed on four basic assessment principles (Fig. 1):

(1) Dynamic principle. The structure and composition of economic security indicators and their critical values (thresholds) can be reconsidered with changes in macroeconomic trends, strategic priorities, purposes, and objectives on the national or regional scale (phase 1).

(2) Target principle. The system of indicators is based on strategic priorities, purposes, areas, and objectives of economic security assurance (phases 2 and 3) outlined in the National Security Strategy of the Russian Federation.
(3) Integrated principle. Feonomic securily indicattors are analyzed in a consistent manner: not only are they measured against their thresholds but also analyzed in the context of changes and in the structure of relations among indicators. The tools of trend and multivariate statistical analyses are used for this (phase 3).

(4) Thresholds principle. The actual values of indicators are measured against their thresholds (critical values), which makes it possible to identify current threats to the system of a region's economic security (phase 4).

The current structure of indicators of regional economic security (sec Table I) is based on the dynamic and target principles and constructed according to the 
strategic priorities, purposes, and areals of assuring the national security of the Russian federation. The 20062015 indicator values for Krasnoyarsk krai, chosen as a typical resource region for the practical lesting of the proposed approach, were assessed using the datal from Rosstat and Krasnoyarskstat; the thesholds were found using data trom $12,4 \mid$, values recommended by national and international bodies, and estimaled valuss of similar lactors for developed market econo mies'. whicly makes it possible to assess the region's econony lor actual competitiveness on the glohal scialc

In addition to measuring the alverage values of economic security indicators for the given period against their thresholds and according 10 the integrated principle, we conducted al trend analysis of asymmetry and excess to assess the kind, equability, and asymunetry of distribution.

In multivariate statistical analysis, we lound lor the sclected 59 indicators paired correlation coeflicients that make it possible to discover signifïcallt direct and inverse relations among the indicators, as well as the absence of relations among specific parameters the initial observation of which would give grounds for supposing the existence ol such relations. The multivariate data analysis included calculation of partial correlation coefficients to assess the extent of linear dependenee between any two indicalors mintus the impact of others and calculation of multiple correlation coefficients that showed the relation between the dependent indicator $X 0$ and the remaining sum of independent indicators $X 1, X 2$, and X58. Stalistical processing, correlation reguession analysis, and clus. terization of the data made it possible not only to iden. tify imbalances (dangers) and areas of increasing threats, but also formalate several economic security paradoxes for resource regions. which manifested themselves in the type of relations among the key indi cators

There are four basic indicators of economic security that determine the state of a region's socioeco. nomic system: (1) life expectancy; (2) the ratio of the region's average per capita income to the average Russian per capita income: (3) the shate of products made by sectors in the fifth and sixth techuological paradigms in the total industrial output; (4) the ratio of GRP per capita to worldwide averalge (GDP per capita We have laken the basic indicalors for dependent variables and constructed the linear equations of multiple regressions, which allowed us to define the indicators that most strongly influence these variables. It is necessary 10 understand this type of relations in order to develop a smart regional socioeconomic policy and deternine the steps and actions that can have the target effect on the basic parameters.

\footnotetext{
The primary statistics were borrowed from OlCI) IBB (IRI. hatp://stats.oced.org)
}

\section{Paradoxes of Liconomic Security}

The sale zone' (by average value) covers only 1701 the 59 studied indicators of Krasnoyarsk krai's eco nomic security. The average values of the 17 indicators are boldfaced. They are largely conditioned by the region's industrial profile and regional presence of major corporations (physical industrial output index, invesinent level, unemployment rate) and linked witl them via quality of life indicators (poptiation income/expense ratio, level of own fiscal calpacity, specific factors of decentralised financial resources)

The escalation of threats (indicator prethesholds or decreasing indicator values) has to do with imbatances in social wellare, industry, and the financial seetor. The alfordability of healtheare services has dropped below the security threshold.

There hats been a critical decline in the share of investments in infrastruclural sectors (construction and housing and utilities). $2014 \ldots 2015$ matred the lirst time since 1998 crisis that personal expenses in the region had exceeded personal income. In 2015, the average per capita income was a mere $89 \%$ of the average Russian. The purchasing power has also suffered a decline: whereas five years ago one room apartments made only a third of all the new housing commissioned, in 2015 their share was already $50 \%$. The share of population with income below mininum subsis. tence level exceeded $19 \%$

The quality structure of the economy has also aggravated. The share of manufacturing in industrial output has dropped by $22.5 \%$ over the last decade (Fig. 2) at the expense of the growing mining that fosters product exports with a low level of value added and secures implementation of budget revenues. The investments in economy have dropped $1021.9 \%$ of GRP and are sustained by investments in major corporate invest ment projects. In 2015 the physical industrial output index was $98.9 \%$ of the ligure in 2014 . The lile quality is alfected by the translormation of the status of Krasnoyarsk krai from a developed industrial region with a diversilied economy to a national storehouse with the dominant role of mining mono-enterprises. The region's average per capita amount of havardous substance emissions into the atmosphere is 66 times ats high as the average higure for the Organization for liconomic Cooperation and Development (Ol:CD) members and the share of employees who work in harmful and hazardous labor conditions is 1.8 times as high as the same average figure for the OI:CD members. It is against this backdrop that the total population incidence of diseatse is growing, including socially critical diseases. The life environment has also been degrading: in 2015, around $45 \%$ of

\footnotetext{
Here and below, a safe none is understood as the conomic standing in which the economic security index does not reach its thresholds, whether at the eurrent level or at the average level for severat periods.
} 


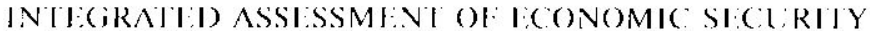

Table I. Indicators of regional economic security in accordanee with the strategie priorities of Russiat s national securily and their average values lor Kralsnoyarsk krai

\begin{tabular}{|c|c|c|c|c|}
\hline Purpose & Areal & Indicalor & Threshold & $\begin{array}{c}\text { Averiage } \\
\text { vilue } \\
\text { fior deciade }\end{array}$ \\
\hline \multicolumn{5}{|c|}{ Strategic prionity: improved lif' quality } \\
\hline \multirow{11}{*}{ 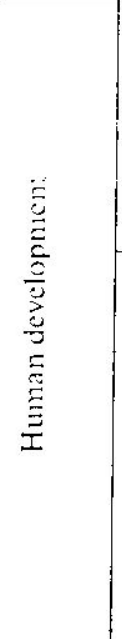 } & \multirow{5}{*}{ 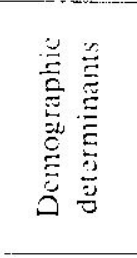 } & 1.ile expectancy, years & $<75.00$ & 67.8 .3 \\
\hline & & Aggregate birth ratte & $\leq 2.15$ & 1.63 \\
\hline & & Mortality ratc & $\leq 10.00$ & 13.23 \\
\hline & & Nallual population increalse als redalced lo migration increatse & $=1.00$ & 0.82 \\
\hline & & Replacement rate, number ol kids per $10(0)$ people above employable age & $>1000$ & 890 \\
\hline & \multirow{2}{*}{ 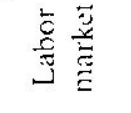 } & L'nemployment rate according to ILO technique, "\% & $<7.00$ & 6.87 \\
\hline & & Shate of people with higher education involved in economy. "/\% & $>4.5,(0)$ & 25.56 \\
\hline & \multirow{4}{*}{ 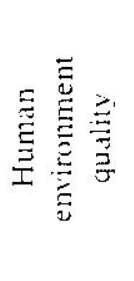 } & $\begin{array}{l}\text { Total morbidity rate, number of initially identified disease cases per } \\
\text { lo00 people }\end{array}$ & $<7,60.101$ & $80 \times 43$ \\
\hline & & Ilazardous substance emissions per capital, $t$ & $>0.015$ & 0.990 \\
\hline & & Share of socially eritical diseases in total amount of diseases, $\%$ & $\leq x .00$ & 5.34 \\
\hline & & $\begin{array}{l}\text { Shatre of employees who work in harmlul and hatardous haber condi- } \\
\text { tions (in industry). } \%\end{array}$ & $<30.00$ & 52.93 \\
\hline \multirow{9}{*}{ 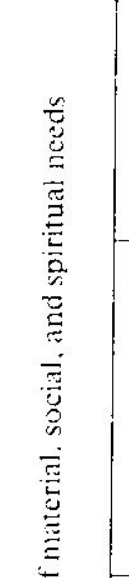 } & \multirow{4}{*}{ 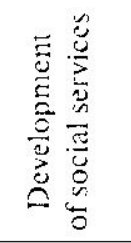 } & Gross educition coverage ol population. "\% & $>95.00$ & 68.93 \\
\hline & & Number of physicians per 10000 people & $>48.60$ & 50.68 \\
\hline & & Share of investments in social welfare sectors in total invest ments. $\%$ & $>10.00$ & 2.84 \\
\hline & & $\begin{array}{l}\text { Share of main production assets of social wellare sectors in the total } \\
\text { cost of main production assets, } \%\end{array}$ & $\geq 10.00$ & 5.15 \\
\hline & \multirow{5}{*}{ 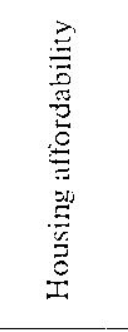 } & Ilousing area per resident, $\mathrm{m}^{2}$ & $\geq 45.00$ & 22.45 \\
\hline & & $\begin{array}{l}\text { Share of one-room apartments in totat amount of new housing put } \\
\text { into commission. } \%\end{array}$ & $<40.00$ & 38.72 \\
\hline & & Share of louscholds in need of improved housing condilions. \% & $<10.90$ & 3.46 \\
\hline & & $\begin{array}{l}\text { Ratio of average market housing cost to average annual family income, } \\
\text { years }\end{array}$ & $<12.00$ & 5.09 \\
\hline & & Average interest rate on mortgige loinn, \% p.a. & $<4.00$ & 13.55 \\
\hline \multirow{4}{*}{ 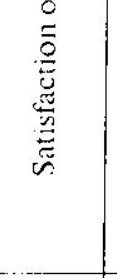 } & \multirow{4}{*}{ 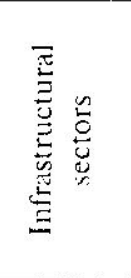 } & Share of unsattisfactory and dilapidated housing, 棌 & $\leq 5.00$ & 4.36 \\
\hline & & $\begin{array}{l}\text { Total share of water supply, sewerage, ind heat supply nelworks in } \\
\text { need of replacement. }\end{array}$ & $<5.00$ & 42.000 \\
\hline & & $\begin{array}{l}\text { Avatilability of atl kinds of transport calculated according to Fingel's law } \\
\text { (coclficient) }\end{array}$ & $>2.00$ & (). 40 \\
\hline & & Share of invest ments in infrastructural sectors in total investments, \% & $>1.5 .001$ & 15.36 \\
\hline \multirow{6}{*}{ 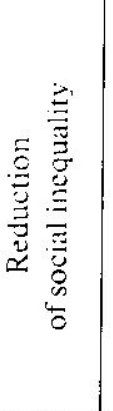 } & \multirow{6}{*}{ 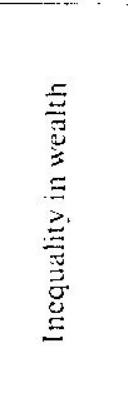 } & Share of loodstuff expenses in total expenses of average household, \% & $<65.00$ & 26.28 \\
\hline & & $\begin{array}{l}\text { Rattio of the average income of the } 10 \% \text { richest to the } 10 \% \text { poorest } \\
\text { inhabitants }\end{array}$ & $<8.00$ & 16.64 \\
\hline & & Personal income/expense ratio & $\geq 1.00$ & 1.09 \\
\hline & & Share of population with income below minimum subsistence level, of & $\leq 7.00$ & 17.15 \\
\hline & & $\begin{array}{l}\text { Ratio of region's average per capila income to average Russian per } \\
\text { capital income (coelficient) }\end{array}$ & $\geq 1.00$ & 0.96 \\
\hline & & Gini coefficient & $<0.34$ & 0.42 \\
\hline
\end{tabular}


Table t. (Conte)

\begin{tabular}{|c|c|c|c|c|}
\hline & & Strategic priorit!: economic srowh & & \\
\hline & 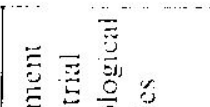 & Wear ratic of matits production alssets. & $<40.00$ & .12 .94 \\
\hline$\underset{\bar{\nu}}{\tilde{2}}$ & 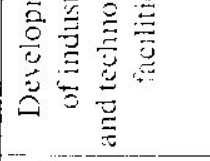 & 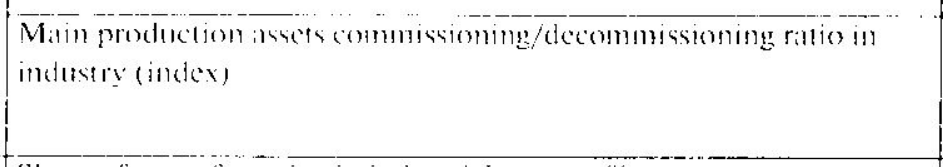 & $>3.00$ & 18.48 \\
\hline$\stackrel{\Xi}{\Xi}$ & $\vec{\Xi} \overrightarrow{0}$ & Shate of manufacturing in industrial output, "te & $>70.00$ & 69.68 \\
\hline$\overline{3}$ & 言言苛 & Shate of machinery indistry in industrial oupus, "s & $>20.00$ & 5.08 \\
\hline$\stackrel{\mathscr{n}}{\ddot{\mathscr{C}}}$ & $\frac{5}{0}$ & Share ol investments in GRP, \% & $>25.00$ & 23.86 \\
\hline$\underset{\bar{E}}{\bar{u}}$ & 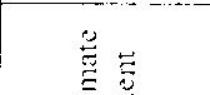 & $\begin{array}{l}\text { Ratio ol newly registered enterprises to enterprises closed down } \\
\text { (coellicien1) }\end{array}$ & $>1.00$ & 1.37 \\
\hline & 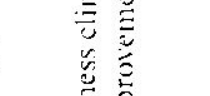 & 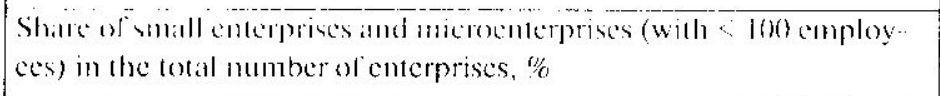 & $>50.000$ & 49.69 \\
\hline & $\stackrel{\bar{m}}{\underline{\underline{\Xi}}}$ & $\begin{array}{l}\text { Ratio of labor productivity of large and medium siacd businesses to } \\
\text { libor produclivity of small businesses and microcmerprises (index) }\end{array}$ & $\geq 1.00$ & 0.74 \\
\hline & 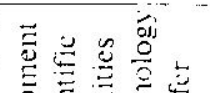 & $\begin{array}{l}\text { Number of employees involved in research and developments. people } \\
\text { per } 1000 \text { cmplovees }\end{array}$ & $>7.9$ & 7.5 \\
\hline$\coprod_{\circlearrowright}^{\beth}$ & 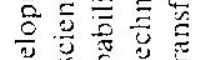 & Share ol expenses on R\&D in (ARP. \% & $\geq 3.00$ & 0.78 \\
\hline 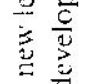 & 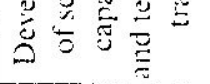 & Vumber of awarded patents per 10000 people & $\geq 6.26$ & 1.71 \\
\hline$\stackrel{\pi}{\Xi}$ & & Share of organizations with active innovation policy, & $>20.00$ & 10.52 \\
\hline$\vec{\Xi}$ & 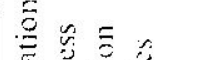 & Shatre of expenses on technological innovations in revenues, \% & $>5.00$ & 3.05 \\
\hline$\stackrel{\Xi}{=} \cong$ & 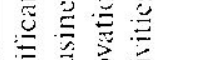 & Share of innovative products in shipped products (in industry), \% & $>15.00$ & $2 . \overline{43}$ \\
\hline 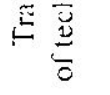 & 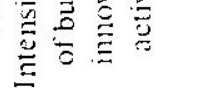 & $\begin{array}{l}\text { Share of products made by sectors in fifth and sixth technological par- } \\
\text { adigms in total industrial output, } \%\end{array}$ & $>20.00$ & 0.79 \\
\hline & & Technological exports/imports ratio in balance of payments. \%) & $>100.00$ & 14.23 \\
\hline & 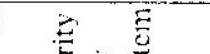 & Consumer price index & $\leq 120.0$ & 108.4 \\
\hline & 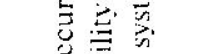 & Share of regional credit institutions in total lending to economy, \% & $\geq 15.00$ & 6.16 \\
\hline & 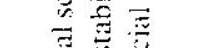 & Banking sitturation index & $\geq 1.0$ & 0.7 \\
\hline & $\stackrel{\Xi}{\Xi}$ & Shatre of overduc loans in lotal loans, \% & $<10.00$ & 3.68 \\
\hline & 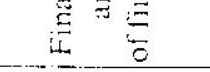 & Averalge cost of lown resources lor nonfinancial organizalions, " " & $<5.00$ & 12.01 \\
\hline 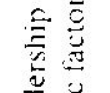 & & $\begin{array}{l}\text { Ratio of growih rate of region's consolidated public debl to GRP } \\
\text { growth rate (index) }\end{array}$ & $<1.00$ & 2.13 \\
\hline 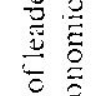 & 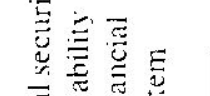 & $\begin{array}{l}\text { Ratio of deficit in consolidated regional budget to own budgetary reve- } \\
\text { nues, } \%\end{array}$ & $\leq 15.00$ & 5.96 \\
\hline 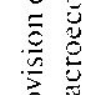 & 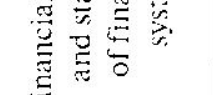 & $\begin{array}{l}\text { Shatre of laxes and fees transferred to consolidated regional budget in } \\
\text { total tax revenues collected in region, } \%\end{array}$ & $>50.00$ & 67.32 \\
\hline 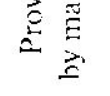 & & $\begin{array}{l}\text { Ratio of sum of taxes and transfers io federal budget to amounit of } \\
\text { linancial aid tramstered from federal to regional budget, } \%\end{array}$ & $<200$ & 270 \\
\hline & & Ratio of (iRP per ciapilil wo worldwide average (ADP per capila, $\%$ & $>100.00$ & 87.25 \\
\hline & 莺 & Physical industrial oupun index & $>102.00$ & 106.76 \\
\hline & $\stackrel{?}{0}$ & 1:xport/impont ratio.\% & $\approx 100.00$ & 518.66 \\
\hline & 总虽 & $\begin{array}{l}\text { labor productivity in economy ( ratio of (iRP to number of employ- } \\
\text { ees), USD IO00 }\end{array}$ & $>49.31$ & 23.05 \\
\hline
\end{tabular}




\section{IVTE(IRATIE ASSESSMENT OH ICONOMIC SHCOERTY}

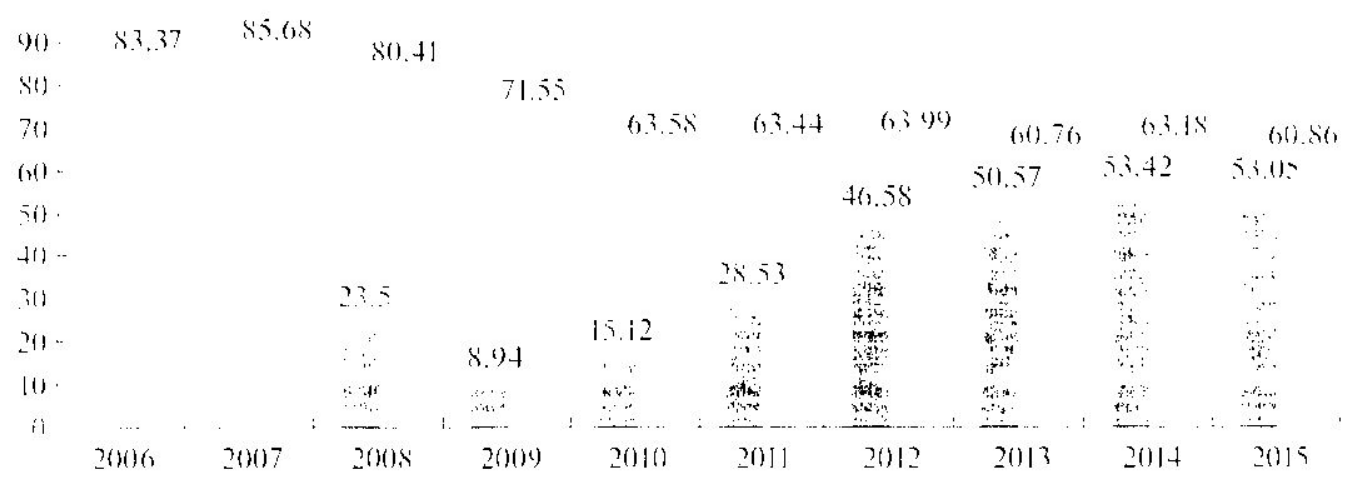

Share of taxescollected in region and transferred to federal budget

Shate of mantakturing in region's industrial output

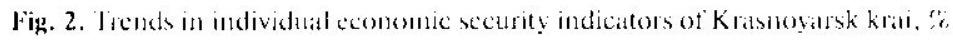

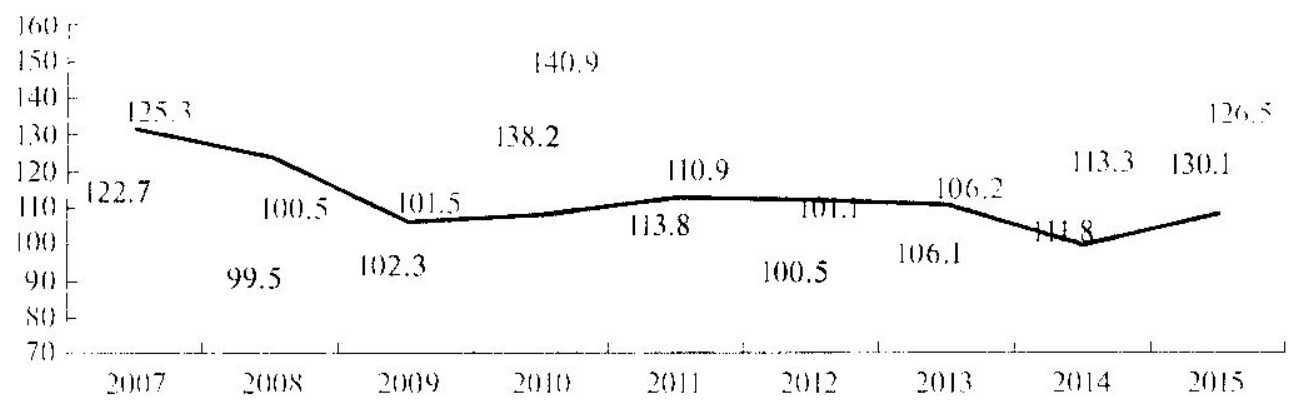

(ivowth rate ol tabor productivity. chatulike:

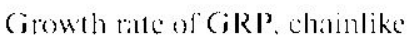

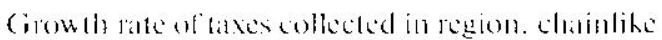

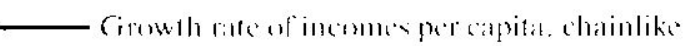

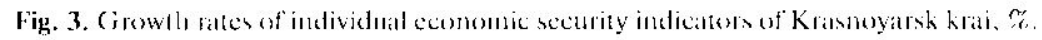

all the region's public utility networks were completely worn out and needed replacement.

In addition. Krasnoyarsk kraits chances of eliminating the imbalances on its own are rapidly waning: the sharpest decline in indicators has been observed in the field of financial security. In $201554 \%$ of all the tax revenues collected in the region were transferred to the lederal budget (cf. with $23.5 \%$ in 2008 ), which was six times higher than the transfers from the federal budget to the consolidated budget of Krasnoyarsk krai (see ligs. 2. 3). Because of the imbalanced budgetary policy implemented by the federal govermment, the region's nonconsolidated public debt has increased by 51.64 times over the last 9 years.
Thus, Knasnoyarsk krai is a lypical resource region oriented at sustaining the financial support of national security. However, it does nol always maintain its economic system at a high-quality level or ensure decent living standards for its residents. The growing imbalances in the economy of such regions will sooner or later destabilize the national economy. It is important, iherefore, to have a smart economic policy with a proper balance between the national and the regional needs. To elaborate and implement this policy. it is necessary not only to understand the origin of the imbalanees, but also be aware of the key inflenenes on the degradation of the basic paramesers of sustainable development of regional economic systems. The mul- 
tivarialte statistical analysis applied as patat of the inte graled principle lesps to identify the distribution of critical and uneritical parameters, which explicates the results of linear of multiple regression equations and indicates the relations of the basic economic security indicators with olher influencing litctors.

For instance, life expectancy as a basic socially important factor is mont closely related to the combon ment, including educition level, housing affordability. income of the region 's residents and their propensing lior salvings, and transport atvatilatsility. The impact of the general economic siluation also matlers: people live longer in a diversilied economy with a high share of small husinesses and microbusinesses, as well ats with intense innovation activities and predominantly advaneed technological paradigms. However, life expectancy is not much affected by such seemingly important parameters as morbidity pattern, affordability of healtheare services, and envirommental pollution, which can be explaned by the delered influence of these factors.

The second basic indicator of cuatity of life is the ratio of the region's average disposable per capita income to the average Russian. It illustrates the antair essence of the national income distribution system. The average per capita income of Krasnoyarsh hrai residents, including not only salaries but also pensions, social security benctits, and rental and entrepre neurial income, wals below Russial's averatge level in the entire considered period (except for 2007 and 2008) and ended to drop down even lurther. This is a paradox, because the krais als a resource region is a donor territory for Russia's economic system and is found among the country's top len regions with the highest GRP. If woukd have had the fistest growing (GRP' in the crisis period. with 113 and $126 \%$ in 2014 and 2015 , respectively. The region's labor productivity has been growing al rolghly the same rate (sec rig. 3).

However. Krasnoyarsk krai is characterized by a very asymmetrical cont ribution ol its macrodistricts in the region's labor productivity: this asymmetry is not balaneed against the distribution of personal income by the same groups of districts. lor instance, the stable growth of labor prodectivity is ensured mainly by industriatly developed districts: in 2014 the average labor productivity in Krassloyarsk, Noril'sk, and the Turukhansk municipal district wals RUR $1.6 \mathrm{mln}$, $5 \mathrm{mln}$, and more than $20 \mathrm{~m}$ h. respectively. In the other districts, however, this parameter ranged from RUR 330000) 10 1030000 (see lig. 4). AI the same time, labor remuneration by the macrodistricts does not always show the contribution of the employed population in the ereation of social product: for instance, labor productivity in the Severo-Yenisciskii municipal district, where gold mining enterprises are concentrated, clanged position from the maximum (in 2007) to the minimum range (2014), whereas sala. ries in the district were in the maximum range throughout 20072014 (sec laig. 5). Similarly, the gainfully employed population of the Taimyr Dolgano-Nenelskii and Evenkiiskii municipal districts, which are charackerized by minimum labor productivity, falls within the maximum range at the expense of guaramees and compensations paid out to the inhabi tants of the I:xtreme North.

Correlation analysis has contarmed the unreason ableness of the policy's territorial distribution of income promoted by the besiness commonity and public atuhoritics. The region's average per capita incume does nol corretale with ils laber productivity (. 0.17), physical indust rial output index ( 0.02$)$, and gross regional product (0.05). That is, the income leve] does not depend on the labor input: the entire surplus income of the resource regions is distributed across the country with different degrees of uniformity. The significant correlation of the average per capita income with a ratio of the average income of the $10 \%$ richest to the $10 \%$ poorest inlabilants $(0.89)$ and Gini coeflicient $(0.90)$ highlights the fact that in the resource territories, personal income is statistically leveled with personal income in the country's other regions by the increasing inequality in wealth and social diflerentiation by income. The average per capita income is litte affected by the current structure of the econony, where priority is given to mining. Growth in per capita income can currently be triggered only by the rising tide of hi-tech manulacturing (machinery industry).

Both basic economic security indicators considered above and the influence of disproportionate structures on these indicators confirm the assumplion that, nowadays, a typical Russian resource region develops not for the benefit of its residents but for the benefit of corporations. 'This is confirmed by signifi. cant correlations of two hasic conomic sccurity indicators: gross regional product and total labor produc livity. Their growth in Krasnoyarsk krai depends more on transport availability, investments, small business development, labor produclivity of large businesses, the employment rate, financial market development (by the affordability index of banking services), and people's education level. In addition, labor productivity and GRP show significant negative correlations with the share of the manufacturing (which explatins its stagnation), foreigu trade technological balance, and living standards (the general drop in income is the impetus for growth in labor productivity).

Despite their declared priorities of contributing to the region's sustainable development, the actual pol. icy of large corporations aims at maximizing the current economic benelïts, which negatively affects many of the region's systems.

larst, the regional financial institutions are pushed out by the federal banking networks, the loans granted by which largely determine GRP growth (the coelficient of the paired correlation of (iRP' with the share of regional banks in the total iending is negative and 


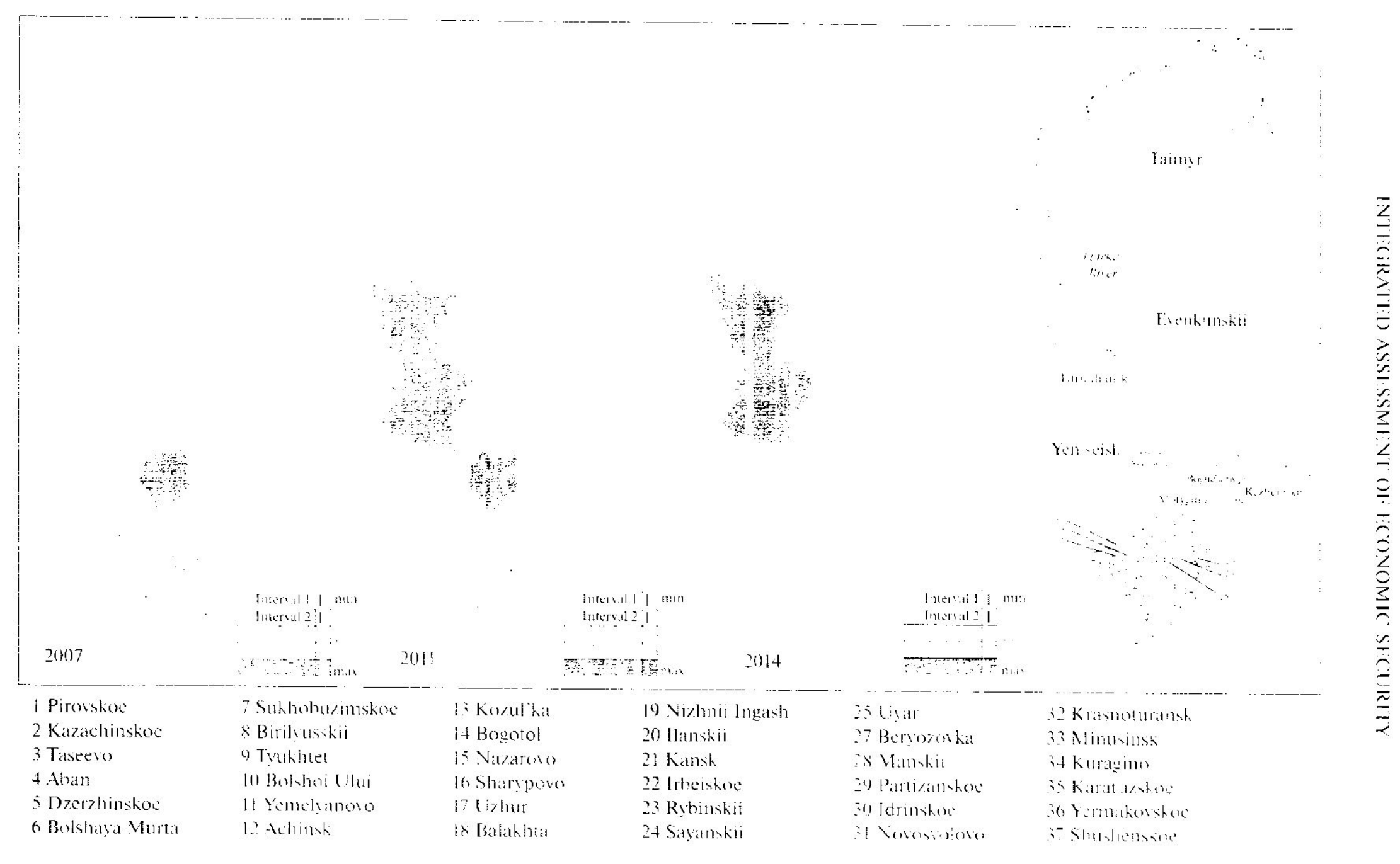

Fig. 4. Distribution of labor procuctivity by muncipal districts of Kannoyats krat telantilest. 


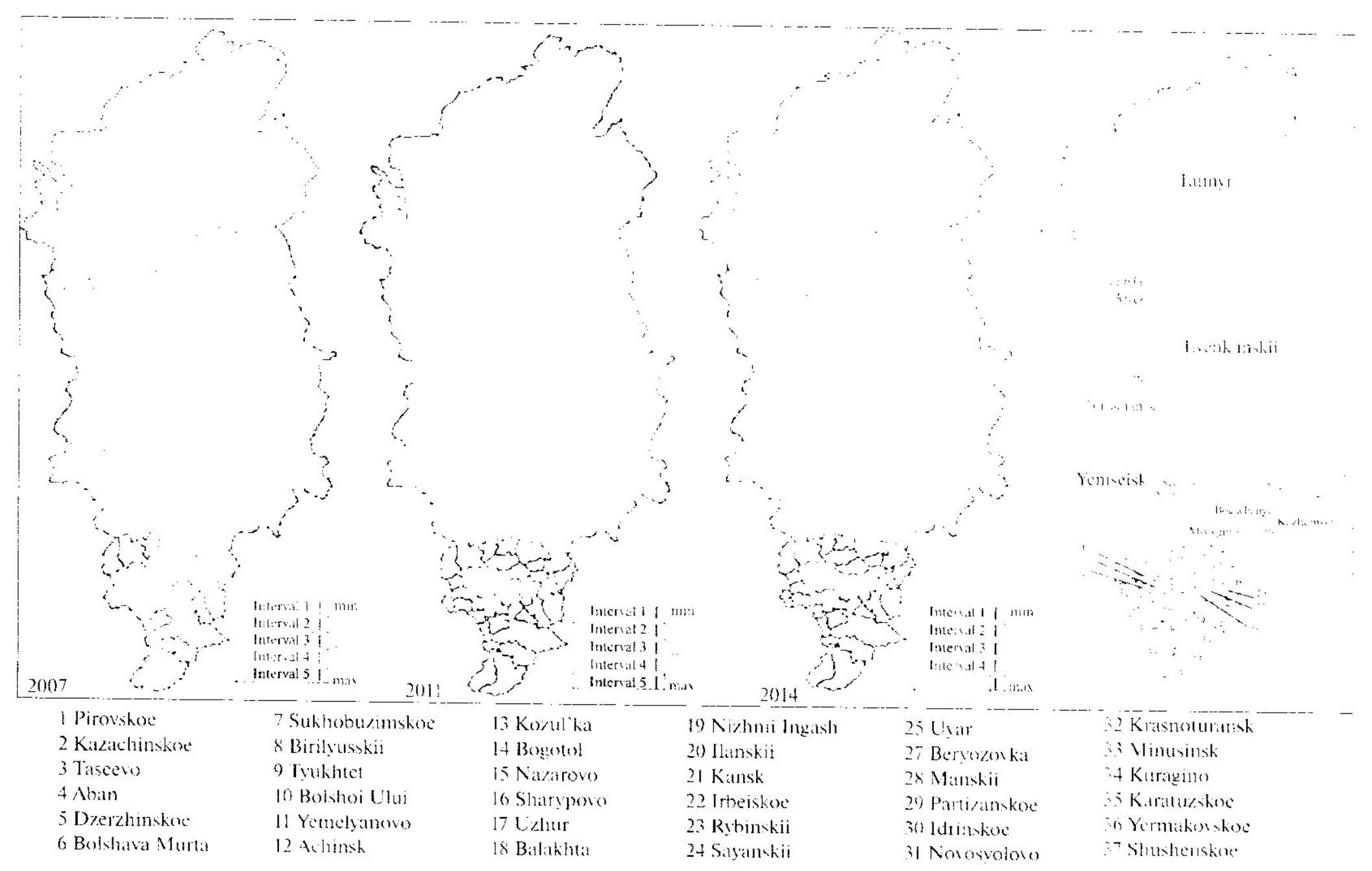

Fig. 5. Distribution of average noninal monthly accued salary of corporate enployees by municipalitics of Kuasnoyarsk krai (quantiles. 
signilicant: 0.85$)$. The share of regional financial institutions in the lending marke dropped from $12.4 \%$ in 2006104.78 in 2015 .

Secondly, the rising entreprencurial activity is con ditioned by provision of services to corporations; in this respect, the economy of Krasnoyarsk krai is based on redistributing natural resource rent. Although the shate of small businesses in such traditional fields of smalt business as the service industry and consumer markel is $80 \%$, it oceupies the minimum shatre of employment in the region's economy (from $32 \%$ in the finatleial and real estate sectors of $3 \%$ in lla matting).

Third, the regional economy is critically dependent on imported technologies and thus already unable 10 develop on its own iechnotogical bisis. Tla region's GRP growth does not correlate with the development of sectors of advanced technological paradigms ( 0.46 ), nor does it correlate with the terri. lory's scientific capabilities (minor positive correlattions are observed with the innovation activity of organizations (0.02), number of awarded patents (0.24), and expenses on technological innovations $(0.21)$ ). Moreover, the development of advaneed economic sectors in the krai show very negative correlations witl the number of researchers ( 0.67$)$, expenses on R\&I) and technological innovations ( 0.55$)$, and is posilively correlated wilh technology imports (0.74). The paradox is that the rising lide of advanced lechnological paradigms in resource regions does not correspond to the current priorities of increasing short-term financial indicators. Proceeding from the signilicant correlations, this rise recuures reduced investments in mining, improved quality structure of main assets in manufacturing, a decline in housing costs (mortgage loan interest rates included), development of all kinds of technological transfer, prioritied focus on local financial institutions, and structural demographic improvements by reducing migration inflow and share ol eleterty people. The development of the sectors of the filth and sixth technological paradigms is currently sustained by large businesses (the negative correlation with the share of small enterprises is 0.79 ) via technology import. This process makes it less and less neeessary 10 commercialize the region's own scientific developments, leads to human capilal assets stagnation, and, ultimately, in the words of Glay ce, to the region s ending up in the trap of lechnological interiority [2, p. 20].

Krasnoyarsk krai still provides decent education and has become an exporter of HQ human assets to other regions and countries: $18 \%$ of graduates ol the region's universities find jobs outside the region. The growll of the shate of edacated population is determined primarily by such lactors as the region's fiscal capacity, entrepreneurial activity of small businesses, statc of housing facilities, housing affordability, and financial market development. The cuality ol human assets shows the most signilicant correlations with the development of the regions's own R\&I) basc. including the mumber of researchers $(0.79)$ and expenses on $\mathrm{R} \& 1)$ and ieclonological innovations (0.92). There is a negative correlation with technology imports ( 0.79 ) That is, a region where educated people decide to settle must not only be able to ensure a bigh cuality olliv ing but also guananted employment in knowledge intensive sectors. Unfortunately, resourec regions show a positive correlation between the share of residents with higher education and the unemployment rate: in the current pattern of matket requirements. there is only a decreased demand for highly educated people. Paired correlation coelficients show the ratio of human asset cjuality to reproduction paramelers: population increase must instead be ensured by a surplus of births over deaths than by migration increas:; children must prevail over elderly people in the pattern ol demographic load on the able-bodicd population.

\section{CONCIIUSIONS}

The proposed integraled approach to diagnosing regional economic security is based on using the indicative method together with trend and multivari ate statistical analysis. It has allowed us to discover signilicant relations annong the basic indicators that determine the standing of a region's socioeconomic system and the corresponding influencing fictors, and define the main economic security imbalances in resource regions like Krasnoyarsk krai.

The main discovered economic security imbalances have to do with the violation of sustainable development principles and are conditioned by the industrial pattern of a typical resourec region and its income-generating ability. The imbalances are concentrated in the fieids of social welfare, industry, and finances. The disproportions of development are manifested in the degradation of the quality structure of economy and reduction in economic diversity aganst the backdrop of envirommental conditions. degrading level and quality of lite, and gradual drain of HQ human assets from the region. At the same lime, the region suffers from the degradation ol its scientific and innovative capabilities against the back drop of the growing internal asymnetry of sociocenomic development across the krai's municipal distriets.

One of the tasks of ensuring economic security on the national scale is to level imbalanees among diflerent types of regions, including resource and agrieultural regions and regions, where financial hows are concentrated. Not only do these imbalances aggravate during crises but they also generate new disproportions and threats that are largely related to uneven lis call capacity and distribution of atverage per capila income, withdrawal of regions' own lax revenues, inequalities in wealth, and environmental effects of industrial expansion aimed at overcoming the crisis. During a long-lime economic recession, resource 
regions carry the burden of sustaming the comatry financially and lose opporlunities 10 turn 10 a new industrial type of society based on knowledge and echnology. This is caused by the preservation of production patlerns based on mining and exporting mincrat resources and products willo low value added. The ever growing needs to balance the consolidaned bud get of lhe Russtan lederation continat to curtal the

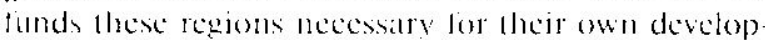
ment. One of the problems that resource regions lice in the lechonological aransition is to tom conditions tor relaning and developing their human atsels! This process depends on prospects for creating high-tech production, demand for skilied human resoures, living enviromment, level and guality of bie. The state policy alone is not enough to form even the basic range of conditions for human potential improvement. Therefore. coordinated joint elforts of the business community and public authorites are necessary.

In this respect, it is ancessary to elaboralle a single alld balanced public policy ol integrated mprovement of regional economic security in light of vartous development paths and problems of dillerent types of regions. An important lask of economic policy lor resource regions will be to encourage regional authorities and corporations to invest in human assets development and create efficient impetuses lor transferring knowledge and technologies to industry.

\section{ACKNOWIIIDGMMINTS}

This study was linancially stuperted by the Kras noyarsk Krailoundation for Support of Research and Development Activities, project "Methodological Approathes to Assessing and lorming the Structural Policy of Human Asset Reproduction for Promoting a Sustainable Development Strategy in the Territories of Krasnoyarsk Krai in the Context of Diversification and Technological Modernization of the Feonomy."

\footnotetext{
'A significant positive correlation of (BRP is the ofle with the economic shate of people with higher education $(0.52)$. This fitctor is correlated with the CiRP growth to the same cxtent ats tamsport awabiability $(0.55)$. viare of small and medium sized businesses (0.53). industrial out put index $(0.52)$. and only at lit

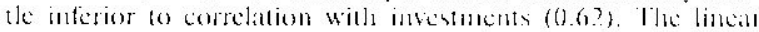

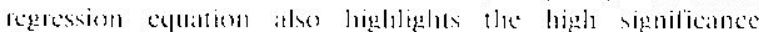
(impact) of educition as (he quality indicitor of thuman assech lor current (iRP vallucs.

"It is extinated bate the share of the edaciled poptalation is largely determined by the demograplac situation forth and death rates, expected life expectancy). homsing atfordability (the positive correlation with the slate of single room abartments is 0.79), housing cuatity (the positive correlation with per capita losusing area is 0.87 ). opportunitics for own business develop mem (1le positive correlation with the share of small businesses is 0.78$)$, the region s fiscal capacity (the positive correlation with the siate of taxes collected in the region and paid on the krats consolidited budget is 0.82$)$. investments in research (the posi live correlations will the anoment of revearch staff expenses on R\&D, atnd mumber of awarded patents ate $0.79,0.9$ ? and 0.85 respectively). Mast of taxise indices are custiced by statc and cor porate policices.
}

\section{RI:FI:RI:NCISS}

1. Abalkin, I. I. Icomomic security of Russia, Vestm. Ross Akad. Nauk, 1997, vol. 67, 100.9, (1). 771776.

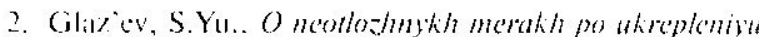
ekomomicheskoi becopasnosti Rossii i vyodu rossiskoi

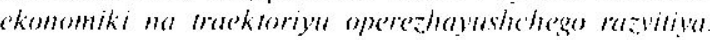
Doklad a Reporl "The i jreent Mealsures to strenethen

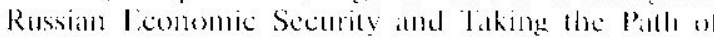
Advaneed Development"). Moscow. Inst. l:kon. Siralegii, 2015

3. Ghacev, S.Yu., Ensuring the econome security of the country: an alfernative course of reforms. Vept: liken. 1997, no. 1, p. 3

4. Ilarionov. A.N., Criteria for economic security, Vop: likon. 1998. no. 10. pp. $35 \quad 58$.

5. Kazantsev. S.V., Zashchishchennost' ekonomiki regionov Rossii (Protection of ficonomy of Russia's Regions) Novosibirsk: Inst. Fkon. Org. Prom. Proizvod.. Sib. Otd. Ross. Akald. Nauk, 2014.

6. Novosclov, A.S., Region as the initial concept of the theory of regional reproduction, Res.: likon. Sotsiol. $2006,170,3$, pp. $3 \quad 1.4$

7. Senchager, V.K., The methods lor ensuring conomic security, Fkon. Reg. 200k, mo, 3, pp. 2839.

8. Senchagov, V.K. and Solov'ev, A.l., Global imbalances, risks, and economic security of Russia, lesm. Fin. Univ., 2015, no. 6, pp. 19.29.

9. Tatarkin, A.I. and Kuklin, A.A.. Changing the parradigm of region's economic security reseitrch. likom. Reg., 2012, no. 2. pp. 2539

10. Babenko, T.I.. Blam, Yu.Sh., Kazantsev, S.V., c1 al., Ugrozy i zashchishchennost ckonomiki Roswii: opyt orsenki (Threals and Security of Russian Fconomy: l:valuation lixperience). Kazantsev, S.V. and Karpov, V.V., IEds., Novosibirsk: Inst. Iikon. Org. Prom. Proizod, Sib. Otd, Ross. Akad Nintk, 2016.

11. Bukharov, A.V., Bukhatrova, I.B., Vorontsovil, I.P. et al., likomomika Krasnoyarskogo krapes sistema regional'noi ekonomicheskoi bezopasnosti y usloviyakh krizisa (Economics of Krasnoyarsk Krai: The System of Regional Economic Security in Crisis), Bukharova, H..B. and Samusenok, S.A., H.ds., Krasnoyarsk: Sib. Fed. Univ. 2016.

12. Hacker, J., Rehm, P., and Schlesinger, M., The insecure American: cconomic experiences and policy attitudes amid the Grealt Recession, Persp. Polit., 2013. IIO. 11, pp. 2.349 .

13. I.tsardi, A.. Schncider, D., and Tufano. P'. Financially Iragile Iouseholds: Fvidence and Implicatons, Working Paper Series No. 17072, Cambridec, MA: Natl. Burcau licon. Res., 201I. http://ww'nber,org/papers/w17072. Accessed September 12.2016.

14. Osherg, I., and Sharpe, A. Ilow should we measure the "cconomic" aspects of well-being? Rev. Income Wealth. 2005 , vol. $51, \mathrm{no}, 2, \mathrm{pp}, 3 \mathrm{ll}-336$.

15. The Economic Security Index: A New Measure for Research and Policy Analysis. Hacker. I.S., Iluber. (B.. Nichols. A., el al.. Eds., San Francisco, CA: Fed. Reserve Bank of San Francisco, 2012. http://www frbsliorg/publications/cconomics/papers/2012/wp12$21 \mathrm{bk}$.pdf. Aecessed September 6. 2016.

\section{Translated by S. Kuznetsoy}

